\title{
Ayurvedic Treatment Protocol for Diabetic \\ Retinopathy: A Randomised Controlled Clinical study
}

Krishna Kumar V ( $\boldsymbol{D}$ drkkempran@gmail.com )

Central council for Research in Ayurvedic sciences https://orcid.org/0000-0002-1741-247X

\section{Vaghela Dharmendra Singh B}

Institute for Teaching and research in Ayurveda, jamnagar

Rajagopala Manjusha

All India Institute of Ayurveda, New Delhi

\section{Research Article}

Keywords: Rasayana Yoga, Ayurvedic Treatment Protocol, Diabetic Retinopathy, Durvadi Ghrita, Marsha Nasya, Takra Dhara

Posted Date: January 20th, 2022

DOI: https://doi.org/10.21203/rs.3.rs-1278380/v1

License: (c) (1) This work is licensed under a Creative Commons Attribution 4.0 International License. Read Full License 


\section{Abstract}

\section{Introduction}

Diabetic retinopathy (DR), the leading cause of visual disability in diabetics, is an important complication of diabetes mellitus (DM). Currently available conventional treatments for DR have certain limitations; considering which Ayurvedic treatment protocol was designed.

\section{Objectives}

The objective was to evaluate the clinical efficacy of the Ayurvedic Treatment Protocol for Diabetic Retinopathy.

\section{Materials and methods}

It was a randomized, controlled, black box design clinical study.Hundred patients of DR were randomly divided into two groups by simple random sampling using computer generated random number tables: Group A: Trial group $(n=70)$ and Group B: Control group $(n=30)$. In Group A preparatory phase included Dipana Pachana (Stomachic \&Digestant), Koshtha Shodhana (mild therapeutic purgation) and Shiro Virechana (eliminative nasal medication). Treatment phase included Nasya (nasal medication) and Pratimarsha Nasya (nasal medication of mild dose) with Durvadi Ghrita, Takra Dhara (pouring medicated buttermilk over scalp) with Siddha Takra and intake of Rasayana Yoga. In Group B, patients were kept under conservative treatment and observed during trial period of three months. Patients of both groups continued with their treatment for diabetes and DR, if any. Two follow-ups were done at an interval of 15 days. The effect of treatment was assessed on the basis of both subjective criteria and objective criteria; since the improvements in both patients' vision and ophthalmoscopic features are necessary in DR to say if the existing stage regressed or maintained.

\section{Results}

Comparison of within groups at two points was analysed by paired " $\mathrm{t}$ " test for objective criteria and Signed Rank test for subjective criteria. Comparison between the groups was analysed by unpaired " $\mathrm{t}$ " test. Trial Group showed better results on Dot blot haemorrhages, Superficial haemorrhages, Hard Exudates, Best Corrected Visual acuity (BCVA), Fasting Blood Sugar (FBS) and Serum cholesterol. Both the groups showed almost similar effects in Post Prandial Blood Sugar (PPBS), Haemoglobin ( $\mathrm{Hb})$, Glycosylated Haemoglobin A1C (HbA1C) and Urine sugar which was statistically insignificant.

\section{Conclusion}

It was concluded that Ayurvedic treatment Protocol is safe and effective in DR.

\section{Key Message}


This study emphasizes the importance of integrated approach in healthcare. Considering merits of Ayurvedic approaches; there is need for collaborative researches for generating evidences at larger scale in treating DR.

\section{Introduction}

Diabetic Retinopathy (DR), the leading cause of visual disability in diabetics, is an important complication of diabetes mellitus (DM) ${ }^{[1]}[2],[3],[4],[5]$. Currently available conventional treatments for DR have certain limitations; considering which Ayurvedic treatment protocol was designed. In Netra Prakashika by Sri Pujyapada Mahamuni, a description of Timira (blurriness of vision) as a cause or complication of Prameha (DM) is obtained ${ }^{[6]}$. Thus DR would be taken as Madhumehajanya Timira. Among trials conducted on DR in different Post Graduate centres of Ayurveda, most were on single procedures like Tarpana (retention of medicated ghee over eyes) or single herbal medicines. As DR is chronic, involvement of Dhatus (tissues) is deep and Dosha dushti (morbidity of body humours) is more, it is difficult to reverse pathogenesis by single medicine or procedure. Thus, a Protocol was designed to test the hypothesis whether the adopted Protocol is effective in DR.

The protocol included preparatory phase - Dipana Pachana, Koshta Shodhana and Shiro Virechana. Treatment phase included Marsha and Pratimarsha Nasya with Durvadi Ghrita, Takra Dhara with Siddha Takra and internal administration of Rasayana Yoga.. Dipana pachana intended to increase metabolism prior to intake of Rasayana yoga. Prameha being a systemic disorder, to eliminate the vitiated Doshas from the body, Koshta Shodhana by Virechana is vital. Moreover retinal exudation and hemorrhagic features of DR simulates Urdhwaga Raktapitta (extravasation /exudation per supraclavicular parts) and its basic line of treatment is again Virechana and thus adopted to reduce the intra vascular pressure as a whole. Shiro Virechana was included for expulsion of accumulated Kapha from Urdhwaga srotases (micro channels). Marsha \& Pratimarsha Nasya, an all sense organ nourishing procedure is added for ocular nourishment. Durvadi Ghrita is Samana (dosha pacifying) as well as Brimhana (nourishing). Hence it not only arrests bleeding; but also strengthens the retinal capillaries which help in reversing and preventing pathogenesis. Takradhara really satisfies the targeted actions in DR viz Urdhwaga Shodhana, Shothahara (reducing edema) and Rakta Sthambhana (arresting bleeding). Rasayana yoga was added to correct the Rasayani daurbalya (fragile micro vasculature in retina) which is evident in DR.

\section{Subjects And Methods}

Selection of Patients

Hundred patients diagnosed as DR (based on International Clinical Disease Severity Scale for DR) were recruited from Outpatient department of Shalakya Tantra of academic hospital (fig.1) .

Inclusion Criteria: 
The patients of either sex between 30 and 70 years with type 2 diabetes who are not on insulin, with or without visual disturbances, but with detectable ophthalmoscopic features of DR; those with FBS in the range 126 to $220 \mathrm{mg} / \mathrm{dl}$ or PPBS in the range 180 to $300 \mathrm{mg} / \mathrm{dl}$ were included in the study.

\section{Exclusion Criteria:}

The patients with Type-1 Diabetes or Type-2 Diabetes taking Insulin; those with High Risk DR requiring emergency intervention; those with media opacities like Cataract which interfere with ophthalmoscopic findings; those with ocular pathologies like Glaucoma, High myopia, Hypertensive Retinopathy and DR associated with pregnancy; those with BCVA less than $6 / 60$ and who were extremely debilitating and not able to withstand treatment procedures were excluded from the study.

Screening Methods:

Selected patients were subjected to a complete examination; findings were recorded in the specially designed case Performa for DR examination as per Ayurveda and Modern parameters. The examinations carried out were best corrected visdual acuity (BCVA) using Snellen's chart and Jaegar's chart (for near vision), Slit Lamp Examination for any gross pathology in the anterior segment, Ocular pressure with Schiotz tonometry, Fundus examination by Direct Ophthalmoscope, Indirect Ophthalmoscope and colour fundus photography for evidence of DR, and Optical coherence tomography for Retina and Macula thickness. Various laboratory and Ayurveda parameters like Prakriti (constitution) were assessed.

Laboratory investigations included routine blood examination, routine and microscopical examination of urine, biochemical examinations like FBS, PPBS, S. Cholesterol, Hb, HbA1C, Liver Function Test (LFT), and Renal function test (RFT) and were carried out at Clinical Laboratory at baseline and at the end of three months.

Research design

The study was a randomized, controlled, black box design clinical study. Computer generated Random tables were used for the study. The sample size was 70 in Trial group and 30 in Control group.

Intervention

All the patients were randomly divided into two groups: Group A: Trial group and Group B: Control group. In Group A preparatory phase included Dipana Pachana, Koshta Shodhana and Shiro Virechana. Treatment phase included Marsha and Pratimarsha Nasya with Durvadi Ghrita, Takra Dhara with Siddha Takra (Table1) and internal administration of Rasayana Yoga (Table-2) Details of therapeutic intervention are given in Table-3. At the end of this treatment procedure; Marsha Nasya for further seven days and Takra Dhara for fifteen days were repeated in the next two months. Two follow-ups were done with an interval of 15 days. In Group B, patients were kept under conservative treatment and observed till the whole therapy period of three months. Both groups continued with their treatment for diabetes and DR, if any. All the medicines in the trial group except Swarnamakshika Bhasma (which was purchased from Dhootapapeshwar Pharmaceuticals, Mumbai, with Quality Analysis Certificate) were prepared in Pharmacy 
of Gujarat Ayurved University, Jamnagar, Gujarat, India as per standard procedures. The nature and design of the study were explained to the patients and informed consent was obtained. The study was approved by Institutional Ethics Committee (No. PGT/7 A/Ethics/2015-16/2625 dated 11/12/2015) and registered under CTRI with CTRI No. CTRI/2016/04/006803 dated 07/04/2016. Data collection was from April 2016 to September 2017. During the study, patients were asked to adhere to the treatment protocol and report any adverse events to the investigator at the earliest. Any manifestations either existing or new during the course of intervention that causes considerable distress were screened for possible adverse events.

Criteria for assessment

Primary Outcomes:

The primary outcomes were objective signs like BCVA; ophthalmoscopic signs like superficial haemorrhages, dot blot haemorrhages, hard exudates, cotton wool spots, neo vascularisation disc, neovascularisation elsewhere and fibro vascular proliferation; subjective symptoms like diminished vision, blurred vision, frequent changes in presbyopia glasses, perception of flashes of light, floaters and problem for dark adaptation. Specialized scoring pattern was adopted for symptoms.

Secondary Outcomes:

The secondary outcomes were FBS, PPBS, Urine sugar, Serum Cholesterol, Haemoglobin, HbA1C, LFT, and $\mathrm{KFT}$.

Statistical methods

Results were assessed in terms of percentage relief and statistical evaluations. Statistical analysis was carried out using Sigma Stat 3.1. Comparison of within groups at two points was analysed by paired " $\mathrm{t}$ " test for objective criteria and Signed Rank test for subjective criteria. Comparison between the groups was analysed by unpaired " $\mathrm{t}$ " test.

\section{Observations}

A total of 100 patients participated in the study. No patients in either group reported any adverse effects. Ten patients dropped out were later excluded from the study (Fig-1). The incidence of sex in the groups shows male preponderance (57.00\%) as compared to females (43.00\%). Maximum were house wives (38.00\%), followed by $25.00 \%$ retired. In dietary etiological factors $20.00 \%$ were having excessive use of curd. Maximum $66.00 \%$ of patients were taking Madhura Rasa (sweet) dominant diet and $55.00 \%$ of patients were taking Snigdha Guna (unctuous nature) dominant diet. It was observed that $63.00 \%$ patients were of Pitta Kapha Prakriti. All (100.00\%) patients were having complaints of diminished vision, followed by $18.00 \%$ of patients having complaints of blurriness of vision. No patients had complaints of frequent changes in presbyopia glasses, perception of flashes of light, floaters and problem for dark adaptation. Ninety five percent patients had Non Proliferative DR (NPDR), five percent had Proliferative DR (PDR) and four percent had Diabetic Macular Edema (DME). Maximum 73.00\% were having dot blot haemorrhages. 
Superficial Haemorrhages were seen in $49.00 \%$. Sixty percent patients were having hard exudates. Signs of PDR like Neo Vascularisation Disc and fibro vascular proliferation were few. Ninety six percent patients had gradual onset of ocular complaints and four percent had sudden onset. Maximum $48.00 \%$ was having history of Diabetes up to five years while $27.00 \%$ reported onset of Diabetes six to ten years ago. Ninety seven percent patients were having regular control of Blood sugar level. Positive family history was reported in $23.00 \%$ and $77.00 \%$ had no family history of DM. Also $41.00 \%$ were found to be hypertensive.

\section{Results}

On symptoms like defective vision and blurred vision, both the groups had statistically insignificant result $(p>0.05)$ (Table-4).Treatment on Group A was more effective in reducing dot-blot haemorrhages $(p<0.05)$, superficial haemorrhages $(p<0.001)$, hard exudates $(p<0.05)$, and change in BCVA $(p<0.001)($ Table -5 , $6,7,8)$. On lab investigations like FBS ( $p<0.05)$ and $S$. Cholesterol $(p<0.05)$, Group A was better than Group B whereas on PPBS, $\mathrm{Hb}, \mathrm{HbA} 1 \mathrm{C}$ and urine sugar both the groups were showing more or less same results which was statistically insignificant $(p>0.05)($ Table-9,10) There was no statistically significant change in Serum Glutamic Oxaloacetic Transaminase (SGOT), Serum Glutamic Pyruvic Transaminase (SGPT), Urea and Serum Creatinine in Trial group ( $p>0.05)$ after taking Rasayana Yoga. In Trial Group, out of 62 patients, four ( $06.45 \%)$ got moderate improvement after the completion of treatment, $23(37.09 \%)$ got mild improvement and 35 (56.45\%) remained unchanged. No eye showed progression. In Group B, out of 28 patients, two (07.14\%) got moderate improvement after the completion of treatment, $06(21.42 \%)$ got mild improvement, $18(64.28 \%)$ remained unchanged and two $(7.14 \%)$ showed worsening in condition.

\section{Discussion}

In 2010, of an estimated 285 million people worldwide with diabetes, over one-third have signs of DR, and a third of these are afflicted with vision-threatening diabetic retinopathy (VTDR), defined as severe NPDR or $\mathrm{PDR}$ or the presence of $\mathrm{DME}^{[7]}$. These estimates are expected to rise further due to the increasing prevalence of diabetes, ageing of the population and increasing of life expectancy of those with diabetes. It is the need of the hour to search an alternative effective approach through Ayurvedic treatment in preserving the eye sight of diabetic patients worldwide and to improve their Quality of Life. Ayurvedic approach differs from other contemporary systems in its holistic approach-which encompasses systemic and local purificatory /preparative procedures followed by administration of target specific medicines. In the case with DR, these include drugs that act on micro-angiopathies and correct the health of capillaries. They also help in establishing the normalcy of the altered blood retinal barrier reducing the edema. The judicious use of detoxification procedure in Ayurveda such as Koshta Shodhana and Nasya checks the bleeding from retina and revitalizes the retina reducing the chances of recurrence. Keeping all these facts a protocol was designed. As per our knowledge this is the first study done as a protocol in treating DR.

Other studies in India ${ }^{[8]}$ have also shown that men are at greater risk for DR and we have also made similar observation. Maximum patients $(51.00 \%)$ were uneducated. This shows their unawareness towards health status and regular eye checkups following detection of DM. The patients belonging to middle class 
was higher (47.00\%) in this study. It is noteworthy that some studies have also showed the prevalence of diabetes to be higher in the middle income group (12.4\%) compared to lower socio-economic strata ${ }^{[0]}$ (6.5\%).Regarding occupational history, maximum patients being house wives and retired ones, shows association of sedentary life styles and lack of exercise with DR. Avyayama (lack of exercise) is the cause for Santarpanajanya Vikaras (diseases due to over nutrition) which include Prameha ${ }^{[10]}$.

Dietary Nidanas like Madhura Guna, Snigdha Guna dominant diet and intake of curd will lead to Kapha Pitta Kopa (aggravation) and further add on to the disease process. As observed, Pitta kapha Prakriti is at maximum risk to be afflicted as Kapha and Pitta are more involved in the disease pathogenesis. We had maximum patients in NPDR stage and it may be because of the fact that the prevalence of NPDR is more as compared to other stages of $D R^{[11]}$. Since maximum patients were in the stage of NPDR classical signs of NPDR like dot-blot haemorrhages and hard exudates were present in large proportion. Signs of PDR like Neo Vascularisation Disc and fibro vascular proliferation were few. In $48 \%$ patients, the onset of diabetes was within five years and it seems little contradictory as the studies conducted shows that the occurrence of retinopathy symptoms mostly after five years ${ }^{[12]}$. This is to be taken that the history of duration of DM as informed by the patient is of detection of Hyperglycemia; rather than actual occurrence. Majority (96.00\%) patients having gradual onset of ocular symptoms indicates the chronicity and severity of the disease by slow progression. That's why diabetes is said to be slow and insidious killer. Also sudden onset of symptoms occurs in a retinopathy patient in its proliferative stage.

Observation of $41 \%$ patient to be hypertensive shows the relation between hypertension and incidence of DR. Hypertension is an additive risk factor for development of DR. Increased blood pressure has been hypothesized, through the effects of increased sheer stress of blood flow, to damage the retinal capillary endothelial cells in eyes of people with diabetes. The possible mechanisms by which hypertension may affect DR are hemodynamic (impaired autoregulation and hyper perfusion) and through VEGF (vascular endothelial growth factor). This hypothesis has been supported by observations from clinical studies which showed an association between hypertension and the presence and severity of retinopathy. [13]

The line of management in Timira includes Snehana (oleation), Rakta Mokshana (bloodletting), Virechana (therapeutic purgation), Nasya, Anjana (collyrium), Shiro Vasti (retention of medicated oil over scalp), Vasti (therapeutic enema), Tarpana, Lepa (medicated paste) and Seka (ocular irrigation) that are to be followed repeatedly ${ }^{[14]}$ of which Snehana, Virechana (Koshta Shodhana and Shiro Virechana), Nasya, Pratimarsha Nasya and Takra Dhara were followed in this trial because of their suitability. Snehana was done by administering Rasayana yoga along ghee. Dipana Pachana increases metabolic activity and helps to digest/assimilate and excrete the metabolic waste accumulated in the tissue and system, thereby clearing the Srotas (microcirculation channels). Shivkshara Pachana churna[15] and Amapachana vati were selected because of their Amapachana (digestion of undigested metabolic waste) property. Trikatu Churna[16] was used for Deepana Pachana as it is indicated in Prameha by Acharya Sushruta. Chitrakadi Vati was selected as it is both Amapachana and Dipana. ${ }^{[17]}$ 
Koshta Shodhana expels out accumulated Kleda (moisture) from the body, which possibly helps in reduction of retinal and macular edema. Moreover, as the features of Madhumehajanya Timira are similar to Urdhwaga Raktapitta (Bleeding through upper orifices); Koshta Shodhana was used as Pratilomahara Chikitsa $^{[18]}$. Koshta Shodhana was done with Eranda Bhrishta Haritaki and Avipattikara Churna [19]. Eranda Bhrishta Haritaki was selected as it has Vata Shamana property. Avipattikara Churna was selected as indicated in Prameha.

Nasya yogas are also described for Timira because nose is a gateway of drug administration in case of Urdhwajatrugata roga (diseases above clavicle). Acharyas have recommended all efforts to strengthen the eyes by resorting to Nasya, Anjana, etc in Timira Chikitsa[20] .Moreover for diseases like Raktapitta, Nasya is a good modality of treatment. So Marsha Nasya was selected in the trial. But before its administration, Shiro Virechana was done with AnuTaila [21]for local Shodhana and Kapha Nirharana (elimination of Kapha) taking into consideration of Kapha predominance in the early retinopathy stages. Marsha Nasya was followed by Pratimarsha Nasya as it strengthens sense organs and prevents further chances of occlusion of Srotas. Here Durvadi Ghrita [22]was selected as it is indicated in Raktapitta. The contents are mostly Sheeta Veerya (cold in potency), Pitta Shamana (pacifying), Rakta Prasadana (blood purifying) and having anabolic effect which nourishes the Dhatus.

Takra Dhara has been widely practiced in Southern parts of our country especially Kerala in various ocular disorders mainly in systemic pathologies like DR. The direct reference is found in the book Sahasrayoga in which it is said to relieve debility, provide strength to eyes, and induce sleep. ${ }^{[23]}$ Due to its soothing and coolant effect, it not only checks bleeding; but also relaxes brain and helps in relieving stress. Takra Dhara is said to be effective in both Prameha and Urdhwanga Roga. Majority of the contents are having either Kashaya (Astringent) or Tikta Rasa (Bitter in Taste) and Laghu-Ruksha Guna (Light and dry). All drugs except Daruharidra (Berberis aristata DC.) are having Sheeta Veeryas. This is the preferred pharmacological properties as far as the haemostatic, blood purifying and coolant actions are concerned. Drugs present in Siddha Takra like Chandana (Santalum album Linn.), Vasa (Adathoda vasica Nees.) Utpala (Nymphaea caerulea Sav.) and Lodhra (Symplocus racemosa Roxb.) have haemostatic properties[24],[25],[26],[27]

The treatment approach for a systemic illness like DR couldn't be holistic without Rasayana (rejuvenating) therapy which has both curative and preventive part to carry out. Here a formulation of nine classically referred Rasayana drugs was selected which are, Pramehahara (reducing blood sugar), Medohara (reducing fat), Raktavahasrotodushtihara (correcting morbidity in vascular micro channels), Vatanuloma (correcting movement of Vata), Sophahara (reducing edema) and Chakshushya (congenial to eyes). Also the angiogenesis, the key to diabetic blindness which is regulated by VEGF'S factor was also kept in mind; hence the drugs having the Anti VEGF'S property were also considered. The plants rich with polyphenols, terpenes, flavanoids, linoleic acid, selenium are found to possess regulate and/or inhibit VEGF's property. Triphala[28](Terminalia chebula Retz.

Embilica officinalis Gaertn.,Terminalia bellerica Roxb)and Guduchi [29]( Tinospora cordifolia [Thunb] Miers.) have these properties. 
On comparing between two groups for defective vision and blurred vision, the difference in the means was not significant, with $p>0.05$. Thus on defective vision and blurred vision none of the treatment were effective. Trial group was effective in reducing dot blot haemorrhages and superficial haemorrhages. This may be due to improving health of retinal vasculature in this short duration of treatment with a significant improvement in haemorrhages. By virtue of Rasayana Yoga, Takra

Dhara and Nasya, the Rasayani Daurbalya is countered; thereby the structural health of the vasculature is strengthened. That's why no fresh haemorrhage was observed.

Trial group was more effective in lowering FBS and S.cholesterol showing that integrated approach in DM gives a better FBS and S.cholesterol control. It is reflecting that treatment by Rasayana therapy after Koshta Shodhana in trial group was helpful in blood sugar and S. cholesterol control along with its maintenance for a long period. Reduction in FBS may be attributed to Pramehahara property of Haritaki (Terminalia chebula Retz.) Amalaki (Embilica officinalis Gaertn.), Haridra (Curcuma Longa Linn.) and Swarna makshika Bhasma (Calcined copper pyrite) present in Rasayana Yoga.[30],[31],[32],[33] There was no statistically significant change in SGOT, SGPT, Urea and S. Creatinine in Trial group. Thus there was no change in liver function and renal function tests in patients of trial group after taking Rasayana yoga. All patients reported betterment in their physical and mental well being which suggests that the protocol is improving the Quality of life and vision. Some reported attainment of good sleep following Takra Dhara which verifies it's soothing and mental relaxing effect. Limitation of our study was small sample size. The Protocol should be tried for a long duration and with more sample size having additional criteria assessment of Quality of vision and Quality of life. Assessment of General Ocular health with regards to Diabetic Ophthalmopathy in addition to retinopathy would also be done.

\section{Conclusion}

Trial group where Ayurvedic treatment was also given with modern-counterpart showed over all better effect. It has helped in breaking the pathogenesis and also in arresting the progression of the disease as it is evident from the study that no eyes showed progression after treatment in the trial group where as the other group showed some percent of worsening also.The better results in the trial group may be due to the improved health status of whole body vasculature specially microvasculature in retina which prevented further exudations and Haemorrhages. Rasayana Yoga is safe as there was no change in liver function and renal function tests in patients of trial group after its intake. This study emphasizes the importance of integrated approach in healthcare. Considering merits of Ayurvedic approaches; there is need for collaborative researches for generating evidences at larger scale in treating DR.

\section{Declarations}

Conflict of interest- declared none

\section{References}


[1] Danaei G, Finucane MM, Lu Y, Singh GM, Cowan MJ, Paciorek CJ, et al. National, regional, and global trends in fasting plasma glucose and diabetes prevalence since 1980. Systematic analysis of health examination surveys and epidemiological studies with 370 country-years and 2.7 million participants. Lancet 2011; 378: 31-40.

[2] World Health Organization Geneva: Global Health Risks. Mortality and Burden of Disease Attributable to Selected Major Risks, 2009 (cited 2019 August 12), Available from: http://www. who.int/ health info/ global_burden_disease/ GlobalHealthRisks_report_full.pdf

[3] Mathers CD, Loncar D. Projections of global mortality and burden of disease from 2002 to 2030 . PLoS Med 2006;3:e 442.

[4] World Health Organization Geneva: Global Status Report on Non Communicable Diseases,2011 (cited 2019 August 8) Available from: . http://apps.who. int/iris/bitstream/10665/44579/1/9789240686458_ eng.pdf

[5] Shaw JE, Sicree RA, Zimmet PZ. Global estimates of the prevalence of diabetes for 2010 and 2030. Diabetes Res Clin Pract 2010; 87(1):4-14.

[6] Pujyapada Mahamuni, Netraprakashika,Chaturtha patala,Sloka 8, $1^{\text {st }}$ edition, Central Council for research in Ayurvedic Sciences, 1999:12.

[7] Yau JW, Rogers SL, Kawasaki R, Lamoureux EL, Kowalski JW, Bek T, et al. Global prevalence and major risk factors of diabetic retinopathy. Diabetes Care. 2012; 35(3):556-64.

[8] Mohan Rema, Sundaram Premkumar, Balaji Anitha, Raj Deepa, Rajendra Pradeepa; Viswanathan Mohan. Prevalence of Diabetic Retinopathy in Urban India: The Chennai Urban Rural Epidemiology Study (CURES) Eye Study. Invest Ophthalmol Vis Sci2005; 46(7): 2328-33.

[9]Connolly V, Unwin N, Sherriff P, Bilous R,Kelly W. Diabetes, prevalence and socioeconomic status: a population based study showing increased prevalence of Type 2 diabetes in the deprived areas. $J$ Epidemiol Community. Health 2000; 54: 173-7.

[10] Agnivesa, Charaka, Dridhabala, Charaka samhita, Sutra sthana, Santarpaneeyam Adhyaya, 22/23, edited by Vaidya Jadavji trikamji Acharya, Chaukhamba orientalia, Varanasi, 2011;123

[11] Yau JW, Rogers SL, Kawasaki R, Lamoureux EL, Kowalski JW, Bek T et. al., Meta-Analysis for Eye Disease (META-EYE) Study Group. DiabetesCare. 2012 ; 35(3):556-64.

[12] Rajiv Raman, Padmaja KumariRani, SudhirReddi Rachepalle, Perumal Gnanamoorthy, Satagopan Uthra, Govindasamy Kumaramanickavel et. al. Prevalence of Diabetic Retinopathy in India: Sankara Nethralaya Diabetic Retinopathy Epidemiology and Molecular Genetics Study Report 2. .Opthalmology 2009;116(2),311-318 
[13] Atlas and text on Diabetic Retinopathy. Ramandeep Singh,Vaishali Gupta, Jaypee Publishers, first edition 2007

[14] . Vagbhata, Ashtanga Hridayam,Uttara Sthana, Timira pratishedha Adhyaya, 47/13, edited by Harishastri $P$, reprint $10^{\text {th }}$ edition, Chowkhamba Surabharati Prakashan, Varanasi, 2011;882

[15] Anonymous, Rasatantrasara, Churna Prakarana, 15th Edition, Krishna Gopal Ayurveda Bhavan, Ajmer, $2001 ; 662$

[16] Sushruta, Sushruta samhita, Sutra sthana, Dravyasangrahaneeyam Adhyaya, 58-59/38, edited by Vaidya Jadavji Trikamji Acharya, Chaukhamba Orientalia, Varanasi, 2014;225

[17] . ibidem Charaka samhita (10), Chikitsa Sthana, Grahanichikitsitam Adhyaya, 96-97/15;520

[18] ibidem Ashtanga Hridayam (14), Nidana Sthana, RaktapittaKasa Nidana Adhyaya, 14/3; 468

[19] ibidem Ashtanga Hridayam (14), Kalpasiddhi Sthana, Virechana kalpa Adhyaya, 21-23/2; 743

[20]. ibidem Ashtanga Hridayam (14) ,Uttara Sthana, Timira Pratishedha Adhyaya, 99/13; 827

[21] ibidem Ashtanga Hridayam (14) , Sutra Sthana, Nasya Vidhi Adhyaya, 38/20; 294

[22] Krishnan V, Pillai G, editors. Sahasrayoga, Ghrita Yoga. Vidyarambham Publishers; Kerala: 26th edition, 2006; 337.

[23] ibidem Sahasrayoga (22), Sudhikrama.; 475.

[24] Shaligrama, Kaiyyadeva Nighantu, Aushadhi Varga, edited by PV Sharma, $2^{\text {nd }}$ edition, Chaukhamba Sanskrit Sansthan, Varanasi, 2006; 233.

[25] ibidem Kaiyyadeva Nighantu (24), , Aushadhi Varga; 6.

[26] ibidem Kaiyyadeva Nighantu (24), Aushadhi Varga,; 268.

[27] ibidem Kaiyyadeva Nighantu (24), Aushadhi Varga,; 208.

[28] Lu K, Chakroborty D, Sarkar C, Lu T, Xie Z, et al. Triphala and Its Active Constituent Chebulinic Acid Are Natural Inhibitors of Vascular Endothelial Growth Factor-A Mediated Angiogenesis. PLoS ONE 2012; 7(8) e 43934

[29] Soham Saha, Shyamasree Ghosh. Tinospora cordifolia: One plant, many roles. Ancient Science of Life 2012; 31(4): 151-159.

[30] .Vriddha Vagbhata, Ashtanga Samgraha, Sutra Sthana, Dwividhaushadha Vijnaneeyam Adhyaya, 23/12, edited by Sharma S, Chaukhamba Sanskrit Sansthan, Varanasi, 2012;120 
[31] .ibidem Astanga Samgraha(30), Sutra Sthana, Dwividhaushadha Vijnaneeyam Adhyaya, 22/12;120

[32] ibidem Astanga Samgraha(30), Sutra Sthana, Dwividhaushadha Vijnaneeyam Adhyaya, 42/12;120

[33] . ibidem Sushruta, Sushruta samhita (16), Chikitsa Sthana, Madhumeha chikitsa Adhyaya, 17/13; 456

\section{Tables}

Table-1: Ingredients of Siddha Takra

\begin{tabular}{|lllll|}
\hline & Drug & Botanical Name & Part used & Proportion \\
\hline 1 & Musta & Cyperus rotundus Linn. & Dried rhizome & 1 part \\
\hline 2 & Amalaki & Embilica officinalis Gaertn. & Dried pericarp & 1 part \\
\hline 3 & Yashtimadhu & Glyccrrhiza glabra Linn. & Dried stem & 1 part \\
\hline 4 & Daru haridra & Berberis aristata DC. & Dried stem & 1 part \\
\hline 5 & Lodhra & Symplocus racemosa Roxb. & Dried stem bark & 1 part \\
\hline 6 & Vasa & Adathoda vasica Nees. & Dried stem, leaves & 1 part \\
\hline 7 & Chandana & Santalum album Linn. & Dried heartwood & 1 part \\
\hline 8 & Utpala & Nymphaea caerulea Sav. & Dried flower & 1 part \\
\hline $\begin{array}{l}25 \text { gms of powder of the ingredients numbered 1 to } 8 \text { of above added in one litre of buttermilk and one } \\
\text { liter of water, mixed thoroughly, kept overnight, filtered in the morning and used in the procedure of } \\
\text { Takra Dhara. }\end{array}$ & & & \\
\hline
\end{tabular}

Table-2: Ingredients of Anubhuta Rasayana yoga 


\begin{tabular}{|lllll|}
\hline & Drug & Botanical Name & Part Used & Proportion \\
\hline 1 & Haritaki & Terminalia chebula Retz. & Dried pericarp & 1 part \\
\hline 2 & Amalaki & Embilica officinalis Gaertn. & Dried pericarp & 2 parts \\
\hline 3 & Vibhitaka & Terminalia bellerica Roxb. & Dried pericarp & 1 part \\
\hline 4 & Haridra & Curcuma longa Linn. & Dried rhizome & 1 part \\
\hline 5 & Guduchi & Tinospora cordifolia [Thunb] Miers. & Dried stem & 1 part \\
\hline 6 & Musta & Cyperus rotundus Linn. & Dried rhizome & 1 part \\
\hline 7 & Yastimadhu & Glycyrrhiza glabra Linn. & Dried root & 1 part \\
\hline 8 & Vasa & Adathoda vasica Nees. & Dried leaves & 1 part \\
\hline 9 & Swarna makshika & - & Calcined copper pyrite & 0.041 part \\
\hline
\end{tabular}

Table-3: Therapeutic interventions adopted 


\begin{tabular}{|c|c|c|c|c|}
\hline & Procedure & $\begin{array}{l}\text { Medicine } \\
\text { used }\end{array}$ & Duration & Posology \\
\hline 1. & $\begin{array}{l}\text { Dipana } \\
\text { pachana }\end{array}$ & $\begin{array}{l}\text { Shiva kshara } \\
\text { pachana } \\
\text { churna or } \\
\text { Chitrakadi } \\
\text { Vati or } \\
\text { Amapachana } \\
\text { Vati or } \\
\text { Trikatu } \\
\text { Churna or }\end{array}$ & $\begin{array}{l}\text { Five to Seven days according to } \\
\text { Koshta of patient }\end{array}$ & $\begin{array}{l}\text { Five to ten grams or one } \\
\text { table with hot water twice } \\
\text { daily before food }\end{array}$ \\
\hline 2. & $\begin{array}{l}\text { Koshta } \\
\text { Shodhana }\end{array}$ & $\begin{array}{l}\text { Avipattikara } \\
\text { Churna or } \\
\text { Eranda } \\
\text { Brishta } \\
\text { Haritaki }\end{array}$ & Next five days & $\begin{array}{l}\text { Five to ten grams with hot } \\
\text { water at } 6 \text { AM according to } \\
\text { Prakriti and Koshta }\end{array}$ \\
\hline 3. & $\begin{array}{l}\text { Shiro } \\
\text { Virechana }\end{array}$ & Anu Taila & Next seven days & $\begin{array}{l}\text { Eight to ten drops instilled in } \\
\text { each nostril at } 9 \text { AM }\end{array}$ \\
\hline 4. & $\begin{array}{l}\text { Marsha } \\
\text { Nasya }\end{array}$ & $\begin{array}{l}\text { Durvadi } \\
\text { Ghrita }\end{array}$ & $\begin{array}{l}\text { After Shiro Virechana, a gap of } \\
\text { one week was given followed by } \\
\text { Marsha Nasya for seven days }\end{array}$ & $\begin{array}{l}\text { Eight to ten drops instilled in } \\
\text { each nostril at } 9 \text { AM }\end{array}$ \\
\hline 5. & Takra Dhara & Siddha Takra & Next 15 days & 30 minutes at $9 \mathrm{AM}$ \\
\hline 6. & $\begin{array}{l}\text { Shamana } \\
\text { Yoga }\end{array}$ & $\begin{array}{l}\text { Anubhuta } \\
\text { Rasayana } \\
\text { Yoga }\end{array}$ & $\begin{array}{l}\text { Started after Koshta } \\
\text { Shodhana and was continued } \\
\text { along with other procedures for } \\
\text { three months }\end{array}$ & $\begin{array}{l}\text { Three grams of powder with } \\
\text { two grams of honey and } \\
\text { five grams of ghee at } \\
\text { bed time }\end{array}$ \\
\hline 7. & $\begin{array}{l}\text { Pratimarsha } \\
\text { Nasya }\end{array}$ & $\begin{array}{l}\text { Durvadi } \\
\text { Ghrita }\end{array}$ & $\begin{array}{l}\text { Started along with Takra } \\
\text { Dhara and was continued for } \\
\text { three months }\end{array}$ & $\begin{array}{l}\text { Two drops instilled in } \\
\text { each nostril at } 5 \text { PM }\end{array}$ \\
\hline
\end{tabular}

Table -4: Comparative Effects in Both Groups on Subjective findings.

\begin{tabular}{|c|c|c|c|c|c|c|c|c|}
\hline \multirow{2}{*}{$\begin{array}{l}\text { Subjective } \\
\text { Findings }\end{array}$} & \multirow[t]{2}{*}{ Group } & \multirow[t]{2}{*}{$\mathbf{N}$} & \multirow{2}{*}{$\begin{array}{l}\text { Diff. in } \\
\text { Means }\end{array}$} & \multicolumn{5}{|c|}{ Unpaired ' $t$ ' test } \\
\hline & & & & S.D & S.E.M & $' t '$ & 'p' & significance \\
\hline \multirow{2}{*}{$\begin{array}{l}\text { Diminished } \\
\text { Vision }\end{array}$} & $A$ & 124 & 0.0726 & 0.260 & 0.0234 & \multirow[t]{2}{*}{0.019} & \multirow[t]{2}{*}{$>0.05$} & \multirow[t]{2}{*}{ NS } \\
\hline & B & 56 & 0.0536 & 0.227 & 0.0304 & & & \\
\hline \multirow[t]{2}{*}{ Blurred Vision } & $A$ & 22 & 0.167 & 0.381 & 0.0777 & \multirow[t]{2}{*}{1.058} & \multirow[t]{2}{*}{$>0.05$} & \multirow[t]{2}{*}{ NS } \\
\hline & B & 6 & 0.000 & 0.000 & 0.000 & & & \\
\hline
\end{tabular}


Table-5: Effect of Trail group on objective findings (Rt Eye)

\begin{tabular}{|c|c|c|c|c|c|c|c|c|c|c|}
\hline \multirow[t]{2}{*}{ Objective findings } & \multicolumn{2}{|c|}{ Mean } & \multirow[t]{2}{*}{ Diff } & \multirow{2}{*}{$\begin{array}{l}\text { \% of } \\
\text { Diff }\end{array}$} & \multicolumn{5}{|c|}{ Paired T test } & \multirow[t]{2}{*}{ Remarks } \\
\hline & BT & AT & & & $\mathrm{n}$ & SD & SEM & $\mathrm{t}$ & p & \\
\hline $\begin{array}{l}\text { Dot blot } \\
\text { Haemorrhages }\end{array}$ & 1.76 & 1.56 & 0.19 & 11.11 & 46 & 0.40 & 0.05 & 3.30 & $<0.05$ & $S$ \\
\hline $\begin{array}{l}\text { Superficial } \\
\text { Haemorrhages }\end{array}$ & 2.12 & 1.83 & 0.29 & 13.63 & 31 & 0.46 & 0.08 & 3.50 & 0.001 & HS \\
\hline Hard Exudates & 1.76 & 1.61 & 0.14 & 8.33 & 34 & 0.35 & 0.06 & 2.38 & $<0.05$ & $S$ \\
\hline Soft Exudates & 1.33 & 1.00 & 0.33 & 25.0 & 03 & 0.57 & 0.33 & 1.00 & $>0.05$ & NS \\
\hline Macular edema & 1.00 & 1.00 & 0.00 & 0.00 & 03 & 0.00 & 0.00 & 0.00 & $>0.05$ & NS \\
\hline BCVA & 2.86 & 2.59 & 0.26 & 9.39 & 52 & 0.56 & 0.07 & 3.44 & 0.001 & HS \\
\hline
\end{tabular}

BT: Before Treatment, AT: After Treatment, SD: Standard Deviation, SE: Standard Error, SEM: Standard Error of means, t:t value, $P$. Probability, S: Significant, HS: Highly Significant, NS: Non Significant, BCVA: Best Corrected Visual Acuity

Table-6: Effect of Trial group on objective findings (Lt Eye)

\begin{tabular}{|c|c|c|c|c|c|c|c|c|c|c|}
\hline \multirow[t]{2}{*}{ Objective findings } & \multicolumn{2}{|c|}{ Mean } & \multirow[t]{2}{*}{ Diff } & \multirow{2}{*}{$\begin{array}{l}\text { \% of } \\
\text { Diff }\end{array}$} & \multicolumn{5}{|c|}{ Paired T test } & \multirow[t]{2}{*}{ Remarks } \\
\hline & BT & AT & & & $\mathrm{n}$ & SD & SEM & $t$ & $\mathbf{p}$ & \\
\hline $\begin{array}{l}\text { Dot blot } \\
\text { Haemorrhages }\end{array}$ & 1.76 & 1.59 & 0.16 & 9.459 & 42 & 0.37 & 0.05 & 2.86 & $<0.05$ & $S$ \\
\hline $\begin{array}{l}\text { Superficial } \\
\text { Haemorrhages }\end{array}$ & 1.96 & 1.73 & 0.23 & 11.86 & 30 & 0.43 & 0.07 & 2.97 & $<0.05$ & $S$ \\
\hline Hard Exudates & 1.74 & 1.64 & 0.96 & 05.55 & 31 & 0.30 & 0.05 & 1.79 & $>0.05$ & NS \\
\hline Soft Exudates & 1.33 & 1.00 & 0.33 & 25.00 & 03 & 0.57 & 0.33 & 1.00 & $>0.05$ & NS \\
\hline Macular edema & 1.00 & 1.00 & 0.00 & 0.00 & 03 & 0.00 & 0.00 & 0.00 & $>0.05$ & NS \\
\hline BCVA & 2.98 & 2.70 & 0.27 & 9.14 & 55 & 0.56 & 0.07 & 3.61 & $<0.001$ & HS \\
\hline
\end{tabular}

BT: Before Treatment, AT: After Treatment, SD: Standard Deviation, SE: Standard Error, SEM: 
Standard Error of means, t:t value, P. Probability, S: Significant, HS: Highly Significant, NS: Non Significant, BCVA: Best Corrected Visual Acuity

Table -7: Effect of Control group on objective findings (Rt Eye)

\begin{tabular}{|c|c|c|c|c|c|c|c|c|c|c|}
\hline \multirow[t]{2}{*}{ Objective findings } & \multicolumn{2}{|c|}{ Mean } & \multirow[t]{2}{*}{ Diff } & \multirow{2}{*}{$\begin{array}{l}\text { \% of } \\
\text { Diff }\end{array}$} & \multicolumn{5}{|c|}{ Paired T test } & \multirow[t]{2}{*}{ Remarks } \\
\hline & BT & AT & & & $\mathbf{n}$ & SD & SEM & $\mathrm{t}$ & p & \\
\hline $\begin{array}{l}\text { Dot blot } \\
\text { Haemorrhages }\end{array}$ & 1.47 & 1.42 & 0.05 & 3.57 & 19 & 0.22 & 0.52 & 1.00 & $>0.05$ & NS \\
\hline $\begin{array}{l}\text { Superficial } \\
\text { Haemorrhages }\end{array}$ & 1.83 & 1.83 & 0.00 & 0.00 & 06 & 0.00 & 0.00 & 0.00 & $>0.05$ & NS \\
\hline Hard Exudates & 1.37 & 1.31 & 0.06 & 4.54 & 16 & 0.25 & 0.06 & 1.00 & $>0.05$ & NS \\
\hline Venous tortuosity & 1.00 & 1.00 & 0.00 & 0.00 & 03 & 0.00 & 0.00 & 0.00 & $>0.05$ & NS \\
\hline BCVA & 2.38 & 2.19 & 0.19 & 8.00 & 21 & 0.68 & 0.14 & 1.28 & $>0.05$ & NS \\
\hline
\end{tabular}

BT: Before Treatment, AT: After Treatment, SD: Standard Deviation, SE: Standard Error, SEM:

Standard Error of means, t:t value, P: Probability, NS: Non Significant, BCVA: Best Corrected Visual Acuity

Table-8: Effect of Control group on objective findings (Lt Eye)

\begin{tabular}{|c|c|c|c|c|c|c|c|c|c|c|}
\hline \multirow[t]{2}{*}{ Objective findings } & \multicolumn{2}{|c|}{ Mean } & \multirow[t]{2}{*}{ Diff } & \multirow{2}{*}{$\begin{array}{l}\% \text { of } \\
\text { Diff }\end{array}$} & \multicolumn{5}{|c|}{ Paired T test } & \multirow[t]{2}{*}{ Remarks } \\
\hline & BT & AT & & & $\mathrm{n}$ & SD & SEM & $\mathrm{t}$ & p & \\
\hline $\begin{array}{l}\text { Dot blot } \\
\text { Haemorrhages }\end{array}$ & 1.60 & 1.53 & 0.66 & 4.16 & 15 & 0.25 & 0.06 & 1.00 & $>0.05$ & NS \\
\hline $\begin{array}{l}\text { Superficial } \\
\text { Haemorrhages }\end{array}$ & 2.00 & 2.00 & 0.00 & 0.00 & 05 & 0.000 & 0.00 & 0.00 & $>0.05$ & NS \\
\hline Hard Exudates & 1.43 & 1.37 & 0.06 & 4.34 & 16 & 0.25 & 0.06 & 1.00 & $>0.05$ & NS \\
\hline Venous tortuosity & 1.00 & 1.00 & 0.00 & 0.00 & 03 & 0.00 & 0.00 & 1.00 & $>0.05$ & NS \\
\hline BCVA & 2.05 & 2.00 & 0.05 & 2.43 & 20 & 0.51 & 0.11 & 0.43 & $>0.05$ & NS \\
\hline
\end{tabular}

BT: Before Treatment, AT: After Treatment, SD: Standard Deviation, SE: Standard Error, SEM:

Standard Error of means, t:t value, P. Probability, NS: Non Significant, BCVA: Best Corrected Visual Acuity 
Table-9: Effect of Trial group on Laboratory findings

\begin{tabular}{|c|c|c|c|c|c|c|c|c|c|c|}
\hline \multirow{2}{*}{$\begin{array}{l}\text { Laboratory } \\
\text { findings }\end{array}$} & \multicolumn{2}{|l|}{ Mean } & \multirow[t]{2}{*}{ Diff } & \multirow{2}{*}{$\begin{array}{l}\% \text { of } \\
\text { Diff }\end{array}$} & \multicolumn{5}{|c|}{ Paired T test } & \multirow[t]{2}{*}{ Remarks } \\
\hline & BT & AT & & & $\mathrm{n}$ & SD & SEM & $\mathrm{t}$ & $p$ & \\
\hline FBS & 133.06 & 164.09 & -31.0 & -23.3 & 32 & 51.90 & 9.17 & -3.3 & $<0.05$ & S \\
\hline PPBS & 184.73 & 187.33 & -2.60 & -1.40 & 30 & 67.95 & 12.4 & -0.21 & $>0.05$ & NS \\
\hline HbA1C & 7.56 & 7.628 & -0.08 & -1.09 & 26 & 1.8 & 0.35 & -0.23 & $>0.05$ & NS \\
\hline Urine sugar & 2.14 & 2.00 & 0.14 & 6.66 & 14 & 1.74 & 2.34 & 0.88 & $>0.05$ & NS \\
\hline $\mathrm{Hb}$ & 12.34 & 12.41 & -0.07 & -0.56 & 30 & 0.69 & 0.12 & -0.65 & $>0.05$ & NS \\
\hline S.Cholesterol & 171.25 & 189.48 & -18.2 & -10.6 & 31 & 31.09 & 5.58 & -3.26 & $<0.05$ & $S$ \\
\hline SGOT & 25.93 & 24.90 & 1.03 & 3.98 & 31 & 11.38 & 2.04 & 0.50 & $>0.05$ & NS \\
\hline SGPT & 20.06 & 21.51 & -1.45 & -7.23 & 31 & 9.33 & 1.67 & -0.86 & $>0.05$ & NS \\
\hline Urea & 29.87 & 31.74 & -1.87 & -6.26 & 31 & 7.76 & 1.39 & -1.34 & $>0.05$ & NS \\
\hline S.Creatinine & 1.20 & 1.18 & 0.01 & 1.60 & 31 & 0.44 & 0.08 & 0.24 & $>0.05$ & NS \\
\hline
\end{tabular}

BT: Before Treatment, AT: After Treatment, SD: Standard Deviation, SE: Standard Error, SEM:

Standard Error of means, t:t value, P: Probability, S: Significant, NS: Non Significant

Table-10: Effect of Control group on Laboratory findings 


\begin{tabular}{|c|c|c|c|c|c|c|c|c|c|c|}
\hline \multirow{2}{*}{$\begin{array}{l}\text { Laboratory } \\
\text { findings }\end{array}$} & \multicolumn{2}{|l|}{ Mean } & \multirow[t]{2}{*}{ Diff } & \multirow{2}{*}{$\begin{array}{l}\% \text { of } \\
\text { Diff }\end{array}$} & \multicolumn{5}{|c|}{ Paired T test } & \multirow[t]{2}{*}{ Remarks } \\
\hline & BT & AT & & & $\mathrm{n}$ & SD & SEM & $t$ & $p$ & \\
\hline FBS & 178.3 & 171.8 & 6.5 & 3.65 & 19 & 72.4 & 16.6 & 0.39 & $>0.05$ & NS \\
\hline PPBS & 210.3 & 223.3 & -13 & -6.18 & 17 & 84.7 & 20.5 & -0.6 & $>0.05$ & NS \\
\hline HbA1c & 7.79 & 7.56 & 0.2 & 2.92 & 18 & 1.62 & 0.38 & 0.59 & $>0.05$ & NS \\
\hline Urine sugar & 2.22 & 1.55 & 0.6 & 30.0 & 12 & 1.22 & 0.40 & 1.63 & $>0.05$ & NS \\
\hline $\mathrm{Hb}$ & 13.25 & 13.22 & 0.0 & 0.27 & 19 & 1.50 & 0.34 & 0.10 & $>0.05$ & NS \\
\hline S.Cholesterol & 155.8 & 169.4 & -13.5 & -8.67 & 19 & 25.18 & 5.77 & -2.3 & $>0.05$ & NS \\
\hline SGOT & 25.73 & 24.73 & 1.00 & 3.88 & 19 & 8.08 & 1.85 & 0.53 & $>0.05$ & NS \\
\hline SGPT & 20.26 & 17.73 & 2.52 & 12.46 & 19 & 5.94 & 1.36 & 1.85 & $>0.05$ & NS \\
\hline Urea & 33.10 & 34.47 & -1.36 & -4.13 & 19 & 14.24 & 3.27 & -0.4 & $>0.05$ & NS \\
\hline S.Creatinine & 1.09 & 1.27 & -0.18 & -16.8 & 19 & 0.31 & 0.07 & -2.5 & $<0.05$ & S \\
\hline
\end{tabular}

BT: Before Treatment, AT: After Treatment, SD: Standard Deviation, SE: Standard Error, SEM:

Standard Error of means, t:t value, P: Probability, S: Significant, NS: Non Significant

\section{Figures}




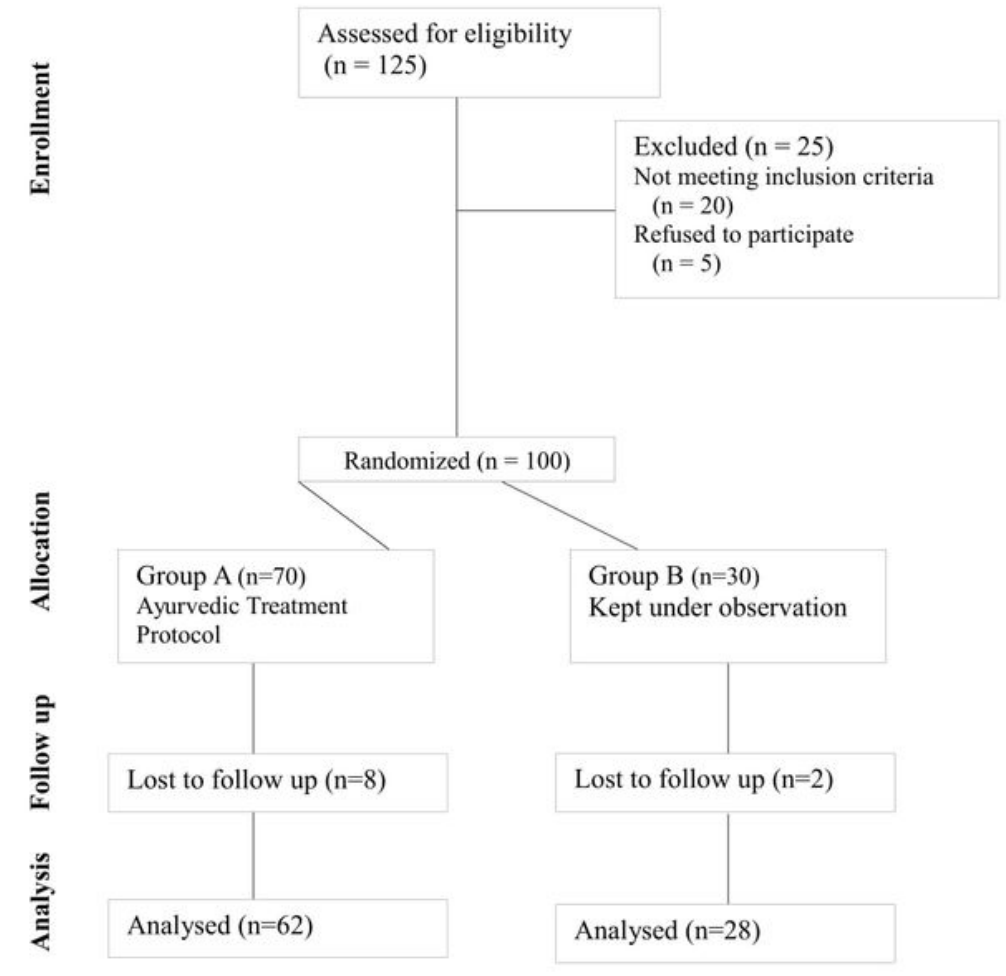

Fig-1 Participant flow chart

\section{Figure 1}

\section{Participant flow chart}

